\section{PP-201夜尿・尿失禁・頻尿で発見されたVUR の臨床的検尉}

\section{豊川市民病院泌尿器科}

津ヶ谷 正行, 伊藤 滒一郎, 岡田 真介

【目的】夜尿、尿失禁、頻尿の小児症例の中には下部尿路奇形が しばしば合併している。この中でVUR 症例について検討した。 [対象・方法]1995年 7 月から 2002 年 6 月までに夜尿、尿失禁、 頻尿を主訴で当科を受診した症例中、135 例に排尿時膀胱尿道 造影（VCUG）を施行した。その中でVURが認められた 31 例を对象とし、手術あるいは保存的治療によるVURの転棎や 夜尿改善率との関係等について検討した。

【結果】初回の VCUG 施行年齢は 5 歳から 13 歳、平均 8.4 歳で あった。VURは国際分類で 3 度以下で、両側 4 例、片側 27 例であった。合併奇形は前部原道狭空 9 例、膀胱悡室 3 例、男 性胵 3 例であった。逆流防止術施行を2 例、経尿道的尿道切開 衍を 5 例に施行した。これらの手術症例と 2 回目 VCUG 未施 行の 2 例除く 22 例に保存的治療を施行し、15 例 $(68.2 \%)$ で VUR が消失し、6 例 (27.3\%) で改善が認められた。夜尿との 関係では、VUR 消失 21 例に対し、夜尿治瘾は 15 例と少なく、 また夜尿治癋までの期間は平均 32.3 ヶでVUR 消失までの 期間平均 17.7 月より長期間を要した。

【結論】夜尿の治笂期間はVUR の消失期間より長く、VUR と夜 尿の治㾟との関係は認められなかった。保存的治療で 1 例を除 き、VURの消失または改善が認められたことから low grade なVURは年長児においても改善しうるものと考えられた。

\section{PP-202}

小児軲巣腫の多䄅性からみた治噔選択 肢

\section{加茂病院 泌尿器科" 聖需病院 泌尿器科2) 名古屋市 立大学 腎・泌尿器科学 ${ }^{3}$}

中根 明宏", 平尾 虫昭", 藤田 圭治"21, 丸山 哲史 ${ }^{3)}$

水野 健太郎 ${ }^{31}$, 小島 祥敬 ${ }^{31}$, 林 祐太郎 ${ }^{33}$, 郡 健二郎 ${ }^{31}$

【目的】小児精坚腫瘍の症例を発見契機、組織型、腫揚マー カー、治療成絓等を他の報告と比較し、手術後経過を合わせ 検討した。対象と方法】1984〜2001 年に経験した 13 例に 対し、発見契機、組織学的診断と年齡、AFP、HCG- $\beta$ の値、 治療法、再発の有無等を検討した。(結果】陰苳水腫との診断 や合併症例が 5 例であった。Yolk sac tumorが 3 例、Mature teratoma か 4 例、Teratocarcinoma、Rhabdomyosarcoma、 Leydig cell tumor、Acute lymphocyte leukemia (ALL)がそれぞれ 1 例、Epidermal cyst が 2 例であり、平 均年齢 4 才 0 ヶ月であった。Yolk sac tumor の 3 例、Teratocarcinoma と Epidermal cyst の 1 例にAFPの上昇を認 めた。化学療法は 3 症例、放射線療法は 1 例であった。再発 は 2 例であった。Yolk sac tumorで化学、放射線療法の施行 例はなかった。結語】陰覆水腫に伴う症例が $38.5 \%$ と注意 が必要と考えられた。非胚細胞性腫㽷が $38.5 \%$ とやや頻度 が高く、組織型は多吱に渡り、ALLの精单転移症例も経験 した。早期に発見した症例に辟重に経過観察をすることで、 化学療法、放射線療法は避けられると考えられた。

\section{PP-203 二分答椎症患者における間歇望尿遵入 時の上部尿路障宫と予後についての梌 钨}

\section{新渴大学大学院 医歯学釉合研究科 腎泌尿器病態学分 野}

小原 健司, 米山 健志, 水澤 隆樹, 新井 啓, 小雄川 悦子 哙木 一也, 高橋 公太

【目的と対象】 間歇的自己测尿 (CIC) により排尿管理を受けている二分 脊椎症患者 35 例 (男性 15 例、女性 20 例) を対象とし、CIC 运入時の上 部层路障害と、その後の経過について検討することを目的とした。成 繶IA 10 例(初診時にすでに上部展路の拉張が諗められた症例)では、 5 例に膀脱㹡大術が施行された。他の 4 例で上部尿路に㹡張を認めない が、経通中 2 例で逆流防止街が施行された。B 群 8 例（経過観察中に上 部家路の昖張が出現し CIC 等入となった症例) では、 3 例に傽胱拡大術 が施行された。他の 5 例で上部尿路に推張を認めないが、経過中 2 例で 逆流防止淮力施行された。C群 7 例（残尿とそれに起因寸る尿路感染症 でCICが迸入された经例)は、全例上部层路に異常を認めない。D 例（低コンフラライアンス膀胼で CIC が勆入された症例）では、8例が上 部层路に異常を認めないが、他の 2 例で膀脱尿管逆流症 (VUR) に対し


CICにより良好にコントロールされた。水腎症、VURに関しては、何ら かの外科的治療が必要となる症例が多かった。上部尿路障害の期間が比

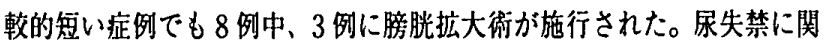
しては、尿道括䄪筋機能不全症例が多数を占めるため抗コリン敦を併用 しても不変あるいは軽度の改善を認めるのみであった。

\section{PP-204 尿管利用傽脱这大術 4 例の检吋}

\section{東京女子医科大学 泌尿器科}

山崎雄一郎,家後理枝,鈴木 万理,東間 紘

【目的】尿管を利用した膀胱拡大術は粘膜面での吸収・産生が ないため術後合併症が生じにくい。しかし消化管に比較して使 用できるマテリアルの量が制限されるため，必要十分な膀胱容 量が得られるかどうか子予測困難な場合が少なくない。われわれ の経験例について術式、経過を検討したので報告する。

【対象と方法】1996-2002 年に当科で施行した男児 4 例。手術 時年龄 5-18 歳。原疾患は前部尿道并 1 例、後部尿道弁 1 例、 原因不明の低コンプアライアンス膀胱 2 例。このうち 2 例は末 期腎不全例で膀脱搪大術後に生体腎移植を施行。尿管膀胱搪大 術は一側腎を摘出し腎后尿管全体を使用した症例が 2 例。左右 の尿管尿管吻合（TUU）を行い、遠位尿管を利用した症例が 2 例。全例で同側の皘单動静脈を温存し得た。1例のみ同側精管 を結禁切離。TUUを行った 2 例は尿管膀脱吻合の既往あり。4 例中 3 例にミトロファノフ式禁制等尿路を作成した。

【結果】膀肶容量 $/ 40 \mathrm{cmH}_{2} \mathrm{O}$ : 術前平均 $39-100 \mathrm{ml}$ 、術後平均 150-430ml。コンプライアンス: 術前平均 $3 \mathrm{ml} / \mathrm{H}_{2} \mathrm{O}$ 、街後平均 $11 \mathrm{ml} / \mathrm{H}_{2} \mathrm{O}$ 。尿禁制：衍後是間展失禁は 3 例で消失、1 例で軽 㨁。排尿方法：2 例が自排尿、他の 2 例は自排尿と CIC を併用。 【結詥】 尿管利用膀胼拡大衍において腎盂尿管を利用できる場 合は十分な膀胱容星が期待できる。遠位尿管のみの利用でも尿 禁制の改善は期待できる。 